Article

\title{
An Inclusive Approach to Partnerships for the SDGs: Using a Relationship Lens to Explore the Potential for Transformational Collaboration
}

\author{
Leda Stott ${ }^{1, *}$ and David F. Murphy ${ }^{2}$ (I) \\ 1 Innovation and Technology for Development Centre, Universidad Politécnica de Madrid (itdUPM), \\ 28040 Madrid, Spain \\ 2 Initiative for Leadership and Sustainability (IFLAS), Institute of Business, Industry and Leadership, \\ University of Cumbria, Ambleside LA22 9BB, UK; david.murphy@cumbria.ac.uk \\ * Correspondence: leda.stott@upm.es
}

Received: 7 September 2020; Accepted: 22 September 2020; Published: 24 September 2020

\begin{abstract}
Partnerships are positioned as critical for the achievement of the Sustainable Development Goals and the United Nations transformational agenda for 2030. The widespread use of terms such as 'collaboration', 'partnership' and 'cooperation' has, however, led to debates about the expectations of such relationships and calls have been made for more rigorous clarification and classification of these related concepts. Drawing upon a comprehensive literature review, we argue in this conceptual paper that the broad spectrum of personal and organizational interactions within, between and across different sectors, domains, disciplines and contexts makes the quest to delineate and categorize these diverse forms of collaboration a seemingly impossible task. We further suggest that such efforts advance a narrow view of partnership as little more than a means to an end, thus limiting understanding of the integrative and intrinsic value of working in this way. We believe that a more inclusive understanding of partnerships may be achieved by exploring them through a relationship lens that acknowledges the importance of inter-personal connections in partnerships more deeply. In doing so, the capacity of partnerships to generate the systemic change that is at the heart of the 2030 Agenda for Sustainable Development may be enhanced and ultimately realized.
\end{abstract}

Keywords: partnerships; sustainable development; SDGs; relationships; transformation; collaboration; inter-personal connections

\section{Introduction}

In December 2019, the four shortlisted contenders for the annual Tate Turner Prize [1] awarded to a British visual artist asked the judges if the prize could be presented to all of them. Oscar Murillo, Tai Shani, Helen Cammock and Lawrence Abu Hamdan described this as a request that was consistent with their values of "commonality, multiplicity and solidarity" [2,3]. In addition to a call for collaboration and inclusion, Shani further observed that the appeal for a collective win was a way of questioning established power structures and "renegotiating hierarchies" [4].

Both the joint petition by the Turner Prize nominees and ultimate co-winners, and the language used by them to frame their request, resonate with what Seitanidi and Ryan (2007) describe as " . . e evidence of a paradigm shift away from arm's length, atomistic and transactional notions of exchange between organizational actors, towards an approach which foregrounds intense interaction, relationships and networks" [5] (p. 256). Relationships, which are defined here as "the way in which two or more people are connected, or the state of being connected" [6], are at the center of this new configuration. A growing interest in collaborative relationships that have empathy and reciprocity at their core [7-10] 
further highlights the important role played by individuals and "underlying emotional and cognitive processes" in these arrangements [11] (p. 105).

Relevant links can also be made to the idea of relational intelligence: "a capacity to engage in relationships: an ability to connect and interact effectively and respectfully with people and stakeholders from various backgrounds, diverse cultures and with different interests, inside and outside the organization, at home as well as across distances, businesses, sectors, countries and cultures" [12] (p. 2). More recently, the idea of relational intelligence has been popularized by psychotherapist Esther Perel as a way of understanding, valuing and enhancing different kinds of relationships [13-16]. Perel's success in linking the personal and the organizational suggests that how we relate to each other at home, work and the wider community is a crucial ingredient for more cooperative and sustainable lives, careers and societies.

On a broader level, these tendencies suggest that collaboration among both individuals and organizations within and between workplaces, families, communities, countries and regions is increasingly needed $[13,17]$, not just to address the complex or 'wicked' problems at the heart of the United Nations (UN) Sustainable Development Goals (SDGs) $[18,19]$ but also to mitigate impediments to their transformational aspiration to "leave no one behind" [20,21].

In this article we argue that those promoting partnerships for the SDGs have much to learn from new and emerging ways of understanding and working in collaboration, such as those manifested by the joint winners of the 2019 Turner Prize. It is our contention that by giving greater consideration to personal connections in organizational relationships, and attention to how these linkages mutually reinforce one another, a more inclusive basis for collaborating for the achievement of the SDGs (and beyond) may be realized.

Following an overview of our methodological approach, we proceed with an analysis of the challenges of defining partnership and categorizing the diverse and evolving forms in which it is manifested. Arguing that due to their wide range and scope, the creation of comprehensive typologies of partnerships is extremely difficult, we suggest that a more inclusive understanding of partnership may be developed by using a relational lens to analyze them. To do this, we present an overview of a variety of different personal and organizational relationships that make use of the terminology of partnership, collaboration and related words to describe and present these interactions. In order to further refine this approach, we suggest that interpersonal connections and the values they espouse are central to partnership and other collaborative relationships that seek to promote the transformation and inclusiveness stipulated in the United Nations 2030 Agenda for Sustainable Development. We build upon this idea by proposing a model for exploring partnership relationships that promotes a move away from the mainly instrumental and extrinsic to embrace interactions that are more integrative and intrinsic at both individual and organizational levels. We conclude with a summary of the rationale for developing a more inclusive appreciation of partnerships and how this might be leveraged to promote the systemic changes required for more sustainable forms of development.

\section{Methodology and Approach}

This conceptual paper aims to provide theoretical and practical insights into how relational aspects of partnering might contribute to the achievement of the transformational change highlighted in the United Nations Sustainable Development Agenda [20]. In order to map the focus area, synthesize the state of knowledge, and serve as a catalyst for future investigation, an integrative literature review of different collaborative forms and characteristics was conducted. Such an approach is designed to encourage assessment, critique and synthesis of a broad range of materials on established or emerging topics so that new theoretical frameworks and perspectives can emerge [22,23]. In this case, the integrative literature review focuses on the "mature" theme of partnership from which a substantial body of research offers openings for review and reconceptualization [23]. This kind of focused and pragmatic approach empowers researchers to consider both the aims and context of a study [24] and to integrate diverse, macro perspectives from a wide variety of relevant domains [25]. 
The literature was located through databases such as Academia.edu, Google Scholar, ProQuest, ResearchGate and Scopus using a Boolean search with keywords such as: 'partnership', 'collaboration', 'sustainable development', 'SDGs', 'relationships', 'transformation', 'collaboration' and 'inter-personal connections'. As well as collating information from a range of different disciplines and thematic areas, the authors also sought to combine insights from both academic and practitioner literature, including guidebooks, practical case studies and opinion pieces. The selection of materials included in the review aimed to capture and combine chronological trends and ideas, including pioneering articles and seminal works on the theme of partnership as well as a variety of more recent resources. The paper further draws upon the extensive knowledge and experience of the authors who have, since the mid-1990s, engaged in both academic and practitioner research relating to a large variety of partnership arrangements addressing sustainable development concerns in different contexts [26-33].

Findings from the literature review are used as the basis for proposing a conceptual model that may be utilized to stimulate further research into relational aspects of partnering in practice. The model, which makes use of resources that inquire into different forms of motivation for second language learning, seeks to encourage deeper consideration of relational dimensions in the development of partnerships for the SDGs.

\section{Partnerships for the SDGs}

The United Nations 2030 Agenda for Sustainable Development sets out a blueprint for a more peaceful and prosperous planet with countries agreeing to meet the interconnected targets of the 17 Sustainable Development Goals (SDGs) [20]. The SDGs focus on measures to end poverty and eliminate hunger, improve access to basic services such as energy, water and sanitation, health and education and reduce inequality, while also tackling climate change and working to conserve our natural environment. The final goal, SDG 17, is a transversal one which aims to strengthen the means of implementing the SDGs through partnerships. SDG 17 promotes a Global Partnership for Sustainable Development led by governments to strengthen international cooperation and development assistance. This Global Partnership is intended to work alongside multi-stakeholder partnerships at global, regional, national or subnational levels that "mobilize and share knowledge, expertise, technology and financial resources to support the implementation of the SDGs" [20] (p. 27).

Although described as pivotal to the transformational efforts required for the realization of all the SDGs, the main focus of SDG 17 (Partnerships for the Goals) is on securing support for increased aid from 'developed' to 'developing' countries with long-term debt assistance, technology transfer and support for a universal, fair and open trading system under the purview of the World Trade Organization [34-39]. Multi-stakeholder partnerships are grouped with "systemic issues" that need to be "enhanced" to support the achievement of the SDGs such as policy and institutional coherence, and data, monitoring and accountability [20]. In general, Goal 17 fails to transmit the much wider potential that partnerships have for generating the transformations at the heart of the Sustainable Development Agenda which include the advancement and endorsement of positive rules, norms and connections at policy level; shifts in individual and organizational behaviors; and the empowerment of vulnerable and marginalized stakeholders [38,40-42]. We suggest that the potential of partnerships to augment these changes may be enhanced by promoting a deeper understanding and appreciation of partnership that explores the interaction between personal and organizational relationships in relation to the SDGs. 


\section{The Challenge of Defining and Categorizing Partnerships}

Although the term 'partnership' has a long history (see Box 1), and the use of partnership language in the field of international development dates back at least half a century [43], it has become something of a buzzword in recent years. The advance of globalization and the increasingly intertwined nature of complex problems faced by society have given rise to a more widely accepted conceptualization of partnership as an association that brings together different sectors of society to pool their diverse resources, capitalize on synergies, and share risks and benefits in order to accomplish something that they could not do alone [44].

Box 1. Partnership: Origin of the term.

The term 'partner' originates from the Latin word 'partitio' or partition which related to the act of dividing, sharing or parting. Following the Norman conquest of England in 1066, both Anglo-Norman French and Middle English used the word 'parcener' to describe a partner as a joint heir with shared inheritance rights to an undivided estate. The word partner in English eventually came to be understood as someone associated with another in a common activity or interest. 'Ship' meanwhile, when linked to a noun, denotes a property or state of being, e.g., relation-relationship; owner-ownership, leader-leadership. Partnership thus demotes the state of being associated with a partner [45].

Since the first UN General Assembly resolution "Towards Global Partnerships" in 2000 [46], the idea of partnership in an international development context has evolved with the most recent of the biennial UN resolutions [47] defining partnership as: "voluntary and collaborative relationships between various parties, both public and non-public, in which all participants agree to work together to achieve a common purpose or undertake a specific task and, as mutually agreed, to share risks and responsibilities, resources and benefits" (A/RES/73/254, para. 4).

In parallel, in the field of sustainable development, partnerships were endorsed as a key approach for achieving environmental and developmental change at the 1992 UN Earth Summit in Rio de Janeiro. While initially centered mainly upon collaboration between public and private organizations, sustainable development partnerships are now accepted as embracing "a broad alliance of people, governments, civil society and the private sector, all working together to secure the future we want for present and future generations" [48].

This evolution is reflected in use of the terms 'multi-actor', 'multi-party' or 'multi-stakeholder partnerships' that are situated at the heart of the UN Sustainable Development Agenda [20,21]. In a related vein, the most recent General Assembly resolution "stresses that partnerships will be critical to the achievement of the Sustainable Development Goals, as an effective instrument for mobilizing additional human and financial resources, expertise, technology and knowledge, while reiterating that partnerships are a complement to, but are not intended as a substitute for, the commitment made by Governments with a view to achieving the Goals" [47] (A/RES/73/254, para. 5).

The partnership landscape, however, extends far beyond the fields of international and sustainable development. The broader partnership terrain encompasses a vast array of collaborative relationships across numerous academic disciplines and professions that have many different forms, names, partners and goals, and operate at global, regional, national and local levels. In a literature review conducted by Creech and Paas [49], for example, the following diverse types of partnerships were identified:

Business Partnerships; Strategic Alliances; Public-private partnerships; Tri-sector or Cross sector partnerships; WSSD [50] Multi-stakeholder Partnerships; Mandated partnerships; Enacted Partnerships; Community partnerships; Negotiated partnerships; Local partnerships; Locally led partnerships; Participatory international partnerships; Non-participatory international partnerships; Nascent partnerships; R\&D (research and development) partnerships; Production partnerships; Transactional partnerships; Integrative partnerships (p. 5) 
It is not surprising then that both the looseness of the term and the variety of different relationships that are being promoted under the banner of 'partnership' have raised questions about how these relationships might best be understood and categorized [33,44,51-53].

While there appears to be general consensus on the impossibility of arriving at a concrete universal definition of partnership, useful efforts have been made to distinguish partnerships from looser collaborative forms such as networks and coalitions [26,27,42,54,55]. Another helpful distinction has been made between statutory or mandated partnerships required by legislation for a specific purpose and more voluntary partnerships among organizations working together for a common strategic purpose [56]. Although the terms are widely used interchangeably [57], Public Private Partnerships (PPPs) in which public sector agencies contract businesses to provide services or build infrastructure have also been differentiated from more flexible, often non-contractual Multi-Stakeholder Partnerships (MSPs) [42]. In addition, it has been noted that cross-sector partnerships such as those involving companies and NGOs cover a wide spectrum from sponsorship and cause-related marketing activities through to much more strategic collaboration on sustainability, policy development and implementation $[26,27,29,58]$.

Further attention has been drawn to the fact that while 'partnership' is most often depicted as a structural form or construct, it can also be construed as 'partnering' - a process or way of working cooperatively [33]. The European Union's (EU) 'partnership principle', for example, outlines a process of engagement and 'multilevel governance' between different social actors and levels of government that ensures the effective delivery of European Structural and Investment Funds [59]. 'Partnership' has also been positioned as a form of 'collaborative' governance in which different actors work together to address societal problems [60-62] and as a paradigm for international development cooperation between North and South [63].

Because of the enormous range of forms and shapes that partnerships take, the quest to develop a comprehensive typology of partnerships is a challenging one [49]. Some examples of the diverse typologies that have been put forward include the three types of collaboration identified in the pioneering work of Murphy and Bendell [26] on business-NGO partnerships:

- Process-oriented: developing strategies, policies and relationships.

- Project-oriented: focusing on discrete activities linked to core business practices.

- Product-oriented: delivering improvements to products, services and sales.

Selsky and Parker [53], meanwhile, propose a typology for cross-sector partnerships that address social issues which outlines four categories of partnerships that are characterized by the actors and sectors involved:

- Non-profit organizations and businesses.

- Governments and businesses.

- Governments and non-profit organizations.

- Actors from all three sectors.

Moving away from a focus on participating organizations, Kelly and Roche [64] classify partnerships involving the Australian Council for International Development according to focus areas that include: 
- Development partnerships working for more effective development at the local level.

- Partnerships to support civil society development.

- Partnerships which leverage a more effective response to complex change situations.

- Partnerships which add quality to the work of all partners.

- Partnerships and alliances for social change.

In contrast, Tennyson [65] presents a partnership typology based on "the choice of partnership structure that is put in place to best support the achievement of particular goals and approaches." This categorization includes partnerships that range from policy and consultative arrangements, and multi-stakeholder relationships at different geographical levels, to partnerships that are temporary and dispersed, and those that focus on learning. A further typology is offered by Austin and Seitanidi [41] who propose a continuum that distinguishes between philanthropic, transactional, integrative and transformational partnerships on the basis of their capacity to create collaborative value.

While all of these efforts provide interesting avenues for exploring partnerships, in addition to their various forms and goals in different contexts, the dynamic and constantly evolving nature of collaborative arrangements makes it impossible to contain them within static categories. Furthermore, these classification exercises focus primarily on organizational and structural relationships and most pay limited attention to the individual, relational and process dimensions that these initiatives involve. The premise of this paper is that personal relationships and dynamics are central to the organizational connections that form the basis of partnerships, and that acknowledgement of this aspect can promote a more inclusive approach to partnerships for the SDGs that, through shifts in individual and organizational behaviors, will enhance their possibilities for achieving systemic change [19,38].

\section{Using a Relationship Lens to Explore the Partnership Landscape}

According to most dictionary definitions, a relationship refers to the way that two or more things or entities are connected, associated or involved. Often used to describe a connection between two people or groups, a relationship also involves how people feel and behave towards each other and may embrace closeness and intimacy through connections such as blood, marriage, civil union or close friendship. Relationships can thus be highly personal and have deep-seated emotional bonds. However, because the focus of most of the literature on partnerships is on organizational relationships, this more personal dimension often goes unacknowledged. We believe that these inter-personal connections are central to partnership arrangements and should be considered in any attempt to classify them.

To explore this premise further, we have sought to map an initial selection of collaborative connections in a schema that includes both inter-personal and organizational contexts or settings that have adopted the language of partnership, partnering and related terms to describe the relationship between two or more entities and/or individuals (see Table 1). 
Table 1. Different types of partnership and collaborative relationships.

\begin{tabular}{|c|c|c|}
\hline Type of Relationship & Examples & References \\
\hline Inter-personal relationships & $\begin{array}{l}\text { Lovers, spouses, families, friends, } \\
\text { neighbors, colleagues, mentors, etc. }\end{array}$ & $\begin{array}{l}\text { Perel [16,66,67]; Chopra, Arora and Saint [68]; Detsky } \\
\text { and Baerlocher [69]; Greenfield and Reyes [70] }\end{array}$ \\
\hline Intra-organizational relationships & $\begin{array}{l}\text { Partners in a business; cross-functional } \\
\text { teams; virtual teams; collaborative } \\
\text { leadership; Industrial relations and } \\
\text { Human Resource Management, etc. }\end{array}$ & $\begin{array}{l}\text { Wilson [71]; Crosby and Bryson [72]; } \\
\text { Cullen et al. [73]; Ibarra and Hansen [74]; Johnstone, } \\
\text { Ackers and Wilkinson [75] }\end{array}$ \\
\hline \multirow{4}{*}{ Inter-organizational relationships } & $\begin{array}{l}\text { Business-Business } \\
\text { (Strategic alliances, joint ventures, etc.) }\end{array}$ & $\begin{array}{l}\text { Hamel, Doz and Prahalad [76]; Kanter [77]; } \\
\text { Swientozielskyi [78]; Todeva and Knoke [79] }\end{array}$ \\
\hline & $\begin{array}{l}\text { Government-Government } \\
\text { (Country alliances/ agreements around } \\
\text { particular themes, between public } \\
\text { sector agencies) }\end{array}$ & Lewis [80]; Pearson [43] \\
\hline & $\begin{array}{l}\text { NGO-NGO } \\
\text { (International-local partnerships, } \\
\text { South-South, North-South; } \\
\text { North-North) }\end{array}$ & $\begin{array}{l}\text { Abrahamsen [81]; Ashman [63]; Crawford [82]; } \\
\text { Johnson and Wilson [83] }\end{array}$ \\
\hline & University-University & Benneworth and Humphrey [84]; Taylor [85] \\
\hline \multirow{11}{*}{ Cross-sector relationships } & Bi sector & \\
\hline & Business-Government & $\begin{array}{l}\text { Reed and Reed [86]; } \\
\text { Selsky and Parker [53] }\end{array}$ \\
\hline & Business-United Nations & $\begin{array}{l}\text { Global Compact LEAD Task Force [87]; Murphy [28]; } \\
\text { Nelson [88]; Stott [30]; Utting and Zammit [62,89] }\end{array}$ \\
\hline & Business-Community & Coombe [90]; Lee [91]; Loza [92] \\
\hline & Government-NGO & $\begin{array}{l}\text { Brinkerhoff [93]; Brinkerhoff [94]; Gazley [95]; Gazley } \\
\text { and Brudney [96] }\end{array}$ \\
\hline & NGOs-International donors & Brinkerhoff and Brinkerhoff [61] \\
\hline & Business-NGO & $\begin{array}{l}\text { Austin [58]; Austin and Seitanidi [41]; Heap [97]; } \\
\text { Murphy [27,54]; Murphy and Bendell [26,60]; } \\
\text { Seitanidi and Crane [98] }\end{array}$ \\
\hline & University-Community & Baker et al. [99]; Benneworth and Humphrey [84] \\
\hline & $\underline{\text { Tri-sector }}$ & \\
\hline & Business-Government-NGO & $\begin{array}{l}\text { Kolk, Van Tulder and Kostwinder [100]; Nelson [101]; } \\
\text { Seitanidi and Ryan [5]; Stadtler [102]; Waddell [103]; } \\
\text { Warner and Sullivan [104] }\end{array}$ \\
\hline & Business-Community-NGO & Kapelus [105]; Sullivan [106] \\
\hline \multirow[t]{6}{*}{$\begin{array}{l}\text { Multi-stakeholder (multi-actor, } \\
\text { multi-party) relationships }\end{array}$} & $\begin{array}{l}\text { A diverse mix of actors and } \\
\text { organizations from different parts of } \\
\text { society working together in networks, } \\
\text { alliances, coalitions, partnerships, } \\
\text { including (among others): }\end{array}$ & $\begin{array}{l}\text { Bäckstrand [107]; Beisheim [108]; Glasbergen [109]; } \\
\text { Pattberg and Widerberg [44]; Rein and Stott [31] } \\
\text { United Nations [20,21,46-48]; Van den Brande [59] }\end{array}$ \\
\hline & Co-creation/Co-production & Stott [110]; Voorberg, Bekkers and Tummers [111] \\
\hline & Collective impact & $\begin{array}{l}\text { Hanleybrown, Kania and Kramer [112]; } \\
\text { Harwood [113]; Kania and Kramer [114] }\end{array}$ \\
\hline & Innovation ecosystems & Granstrand and Holgersson [115]; Mattila et al. [116] \\
\hline & Multipartite Social Partnerships & Andersen and Mailand [117] \\
\hline & Public-Private-People Partnerships & itdUPM [118]; Ng, Wong and Wong [119] \\
\hline
\end{tabular}

The relationship overview in Table 1 provides us with the beginnings of a more inclusive classification of partnership and related collaborative arrangements. These connections have different core objectives, ranging from fulfilment of a concrete task to working towards a longer-term shared goal which may focus on capacity-building, behavioral or policy level change [33,42] which are, in turn, also overlaid by diverse geographical, disciplinary, sectoral and thematic foci. Some examples of the many thematic or disciplinary fields in which we have encountered the promotion of partnerships include: international relations [120,121], international development [63,82,93], humanitarian assistance $[19,122,123]$, disaster risk reduction [124,125], climate change [126-128], sustainable development $[26,44,104,107,129]$, health and social care [130-132], employment [75,133,134] policing [135], medicine and law [136], and access to basic services such as energy, water, 
etc. $[19,32,137,138]$. To these may be added the sector focus of different initiatives (business, government, civil society, etc.) and geographic and administrative levels of operation (local, regional, national, and global/rural and urban).

Clearly then, because of the enormous number of variants outlined above, a 'one-size fits-all' typology will be unable to capture the vast range of collaborative relationships in different contexts. To begin to map these relationships in an inclusive manner we have elected to plot them as a series of concentric rings that embrace both personal and organizational connections (see Figure 1).

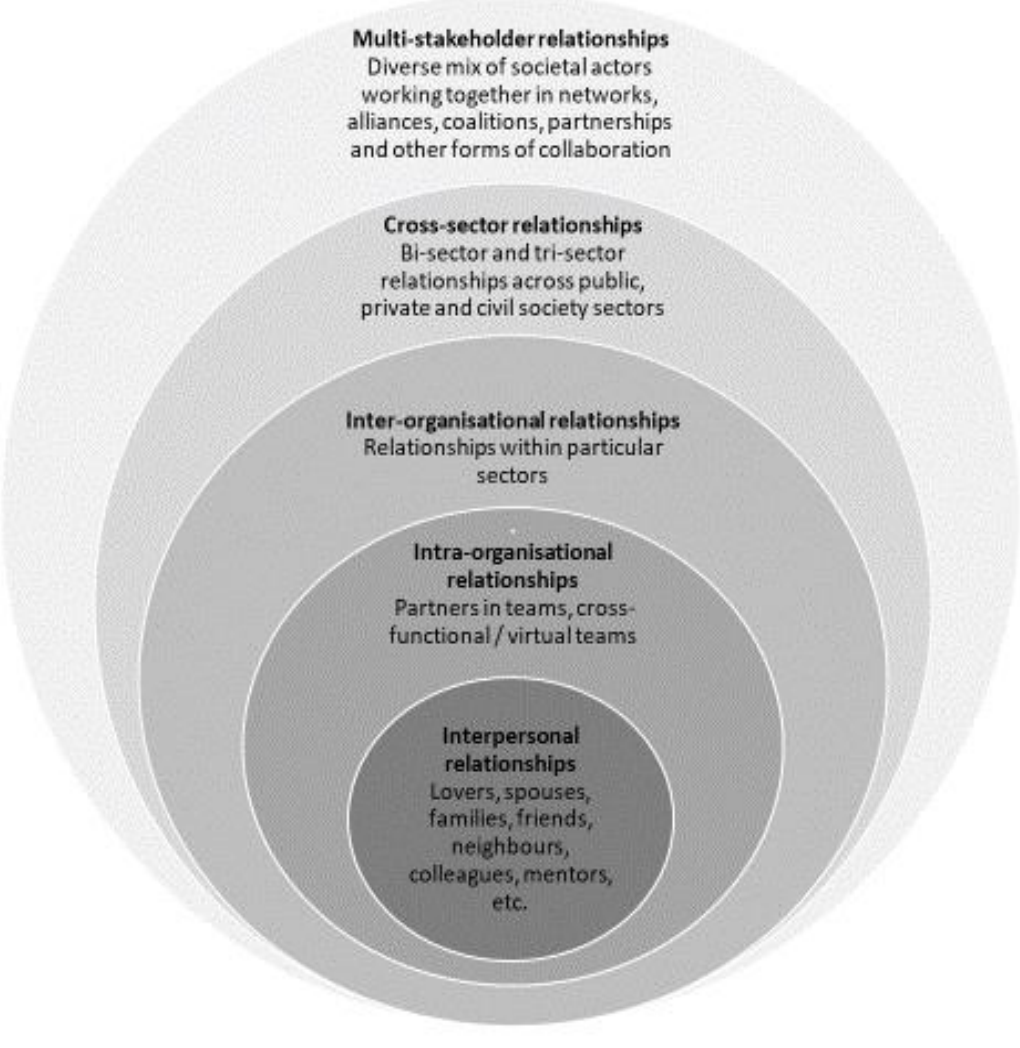

Figure 1. An inclusive map of different types of partnership and collaborative relationships.

Figure 1 positions close individual connections at the center and moves outwards to encompass different organizational connections. By presenting the relationships in this way, we seek to reinforce the point that interpersonal connections are at the heart of all these collaborative arrangements. Such positioning reinforces Battisti's arguments that it is "individuals who work together and engage in partnerships rather than the organizations or the sectors" [11] (p. 96) and that the emotional connections and dynamics that we are likely to encounter in interpersonal relationships are likely to resonate in broader organizational relationships. Awareness of these "underlying emotional and cognitive processes, and articulating and reflecting on them" is thus an important way of understanding the "unconscious mechanisms" that underpin partnership arrangements [11] (p. 105).

Most academics and practitioners interested in personal and/or organizational relationships have tended to look at such relationships separately (e.g., work-life balance). As a result, little consideration is given to how a better understanding of what makes mutually beneficial relationships work at home might inform, influence and enhance relationships at work, between organizations and in the wider world. We believe that this divide is unhelpful and acknowledgement of the interconnections between these spheres is necessary to understand partnership and other collaborative relationships more fully. In this sense, it is our view that 'the personal is organizational' and 'the organizational is personal'. It is also important to highlight that personal and organizational relationships are integrally related to 
the wider geographic, socio-historic, cultural political and institutional settings in which they operate, and that there will be a complex and changing interplay between these different contextual layers throughout the lifetime of a partnership or other form of collaboration.

This notion is echoed by Kolk [139] who states that, "how a partnership actually functions - and thus, can have an impact-also depends on individual factors and the process of interactions, as these can yield not only organizational benefits but also more indirect (trickle) effects within and between the micro, meso and macro levels" (p. 13) (see Figure 2). Attention to the close interaction between individual, organizational and wider contextual levels can thus assist us in more deeply understanding the potential that collaborative relationships may play in supporting the achievement of the SDGs.

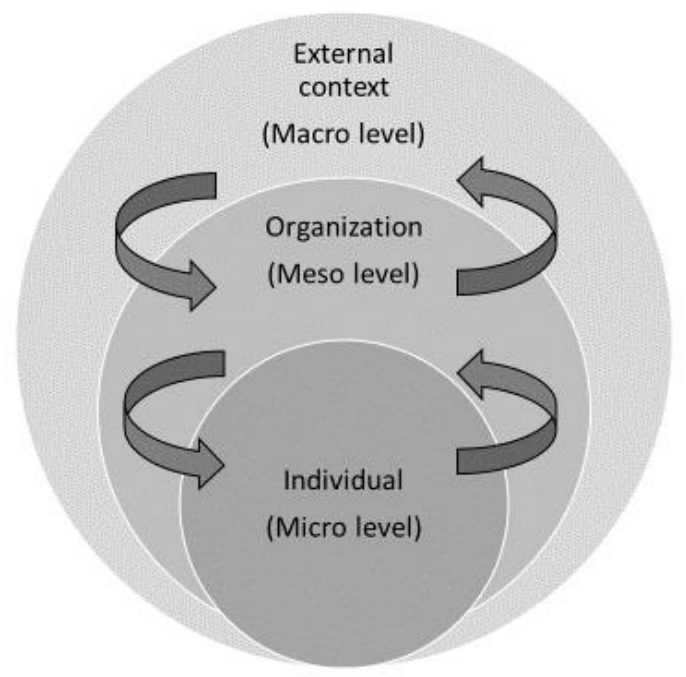

Figure 2. Partnership connections and interactions. Source: Adapted from Kolk [139] and Stott [33].

These ideas also resonate with Organizational Development (OD) theory which focuses on maximizing opportunities for individual and personal development within an organization alongside better alignment of its strategic objectives in the broader operational context [140]. This systems approach endorses linkages between the individual, the organization and the wider environment $[141,142]$ based on a set of guiding values that include:

Humanism (authenticity, openness, honesty, fairness, justice, equality, diversity, respect); participation (involvement, participation, voice, responsibility, opportunity, collaboration, democratic principles and practices); choice (options, rights, accountability); development (personal growth, reaching potential, learning, self-actualization) [142] (p. 331).

According to Rothwell, Stavros and Sullivan [141], "the field of OD can help an organization anticipate, adapt, and respond to transformation and change at any level: individual, team, department, organization, and even society" (p. 16). Acknowledgement that organizational development and change rest critically upon "human dynamics" and individual values and relationships [142], suggests that the personal dimension in partnership and other collaborative arrangements would benefit from further exploration.

\section{The Personal Dimension in Partnerships}

Sloan and Oliver [143] note that most scholarship on multi-stakeholder partnerships has overlooked individual characteristics and interpersonal dynamics. This is further endorsed by Battisti [11] who argues that it is important to understand cross-sector partnerships from an individual perspective, not just an organizational one. The "human element" in partnerships and attention to how individual characteristics such as "personal goals, informal group pressures, and professional backgrounds" can 
shape collaborative decisions is also highlighted by Gazley [95] (p. 655). Caplan et al. [144] further suggest that particular attention should be paid to the different incentives that individuals may have for working in partnership as this will assist understanding of why certain elements of a partnership are working or not.

In addition to assuming different roles as organizational representatives in partnerships, individuals may also play a catalytic role in promoting and improving this kind of interaction by acting as 'partnership brokers'. Further described as "bridge builders", "conveners" or "orchestrators", these individuals have been specifically singled out for mention in a range of publications due to the work they undertake in supporting and shaping collaborative relationships between organizations $[19,40,145,146]$. Indeed, some authors have suggested that those exercising the partnership brokering role may be a new kind of "leader" or "difference maker" [147-149].

The importance of ensuring that leaders in a "connected world" have the relational intelligence "to connect with different people and various stakeholders and to act competently on an interpersonal and ethical basis" is highlighted by Pless and Maak [12] (pp. 1-2). Senge, Hamilton and Kania endorse this view in their call for "system leaders" able to catalyze collective leadership by focusing on the larger system rather than parts of it, "fostering reflection and generative conversations" and promoting a move away from "reactive problem-solving to co-creating the future" [148] (pp. 28-29). Sennett [8] also endorses the demand for reflection and generative conversations by noting that stronger and more meaningful cooperation can be encouraged through a willingness by individuals to listen, seek to understand different and conflicting viewpoints and allow differences to surface through debates that provoke, test and challenge assumptions. This is summarized neatly by Gino [150] who suggests that in successful collaborations, "judgement gives way to curiosity and people come to see that other perspectives are as valuable as theirs." (p. 6).

These arguments clearly position values as central to both personal and organizational relationships and resonate with the depiction of relational intelligence as incorporating emotional and ethical capabilities which include, "being aware of and understanding one's own and others' emotions, values, interests and demands, discriminating among them, critically reflecting on them, and using this information to guide one's actions and behavior with respect to people." [12] (p. 2). Authors such as Bregman [10], Eisler [9], Leadbeater [7] and Sennett [8] further believe that humans have an innate capacity for cooperation and partnership and that it is interdependence between people, rather than organizations, and engagement in a dynamic process of cooperation that has value in and of itself.

The views outlined above promote an understanding of partnership that is much more than simply a vehicle by which different organizations work together to achieve stipulated and concrete targets such as those outlined in the SDGs. Instead, emphasis is placed on achieving outcomes via the process of working in partnership (partnering). Furthermore, if this process seeks to enhance the integration, transformation and systems change that are central to the United Nations Sustainable Development Agenda, then personal connections that are built around values such as empathy, reciprocity and mutual benefit could be a catalyst for a profound global renewal.

\section{Exploring Motivations for Working in Partnerships for the SDGs}

We believe that a relationship lens which focuses on the ongoing value that is derived from personal connections can offer important insights into how more effective partnerships can be developed for the achievement of the SDGs and beyond. This will require deeper attention to the core relational values around which partnerships are built and more exhaustive research into personal and organizational motivations, aspirations and ambitions for partnering.

According to Leary and Acosta [151]: "Two essential requirements for successful close relationships are that the partners value their relationships with one another, and each person recognizes that the partner values the relationship". This notion of mutual benefit is reflected in many of the principles that have been put forward for those working in partnership, which also include openness and the ability to communicate feelings or concerns, alongside fairness and the promotion of equity between 
partners so that their inputs into the relationship are equally valued [11,152]. To these we may also add the values mentioned by the four 2019 Turner Prize winners who, in their call for a collaborative 'win', placed emphasis on the importance of reciprocity and solidarity. Battisti [11] also endorses the importance of an appreciation of diversity, noting that: "differences can be fruitful. While the partner's values, attitudes, opinions and approaches might be different and might create cognitive and emotional tensions, tolerating or working through them is crucial to engage effectively" (p. 106).

Discussion of collaborative values usually highlights the importance of trust as a central principle for strong relationships. Sloan and Oliver [143] note that trust-building is a dynamic process that is built upon both cognitive and affective elements. They describe cognitive elements as including perceptions of trustworthiness that are based upon expectations of predictable and reliable behavior while affective dimensions include emotional feelings such as care, concern and good will. The authors suggest that "a certain amount of cognitive trust is necessary before affective trust can develop" (p. 1859) and that "interpersonal trust can lay the foundation for the development of interorganizational trust" (p. 1860). Sloan and Oliver [143] further reinforce Perel's emphasis on the importance of continuing to explore, learn and grow in relationships, something that is likely to be enhanced when there is a sense of familiarity, closeness and security between partners $[66,153]$.

Elements of interpersonal relationships will inevitably overlap and find expression in the organizational connections that form the basis of partnerships, particularly as a balance needs to be found between process and the achievement of results so that partner efforts are dedicated towards both a common goal as well as relationship-building [11,154]. However, although relational drivers for organizations are not always straightforward and may embrace a complex array of motivations that can change over time, most organizations appear to espouse an instrumental view of partnering that is largely based on its usefulness as a means to an end. Such a view centers upon a conceptualization of partnership in which organizations commit to a relationship that has the potential to achieve goals and impact that a single partner could not achieve alone (see Section 3 above). It is also worth noting that many organizations (and the individuals within them) are mandated to work in partnership and built-in reward systems are in place for incentivizing engagement or, conversely, imposing sanctions upon those that do not promote this kind of involvement [144]. These understandings of partnership contrast substantially with more personal approaches that focus on interdependence between people through their engagement in a dynamic process of cooperation that has value in and of itself [33].

To bring together and explore different individual and organizational incentives for partnering in more detail, we have drawn upon the literature that discusses motivations for second language learning [155-159]. These categorizations embrace two overlapping dichotomies:

- Instrumental vs. integrative motivations -in which instrumental refers to doing something as a means to an end in order to achieve a result or practical goal while integrative pertains to relational connections and a desire to interact with, and become part of, a broader community.

- Extrinsic vs intrinsic motivations-in which extrinsic relates to external mandates for doing something, including the promise of reward(s) or, conversely, to avoid some form of sanction, while intrinsic is about doing something because it is rewarding for its own sake.

These motivations have been outlined in Figure 3 to explore some of the key drivers for working in partnerships to achieve the SDGs.

Although there is growing appreciation of the role of individuals and personal qualities and attributes in partnerships and other collaborative relationships, we believe that the predominant reasons for organizations to partner find expression in the two left-hand quadrants of Figure 3. While accepting that partnerships will require equilibrium between different personal and organizational motivations and dynamics for working in this way, our premise is that, in order to enhance the potential of partnerships for transformation, more work needs to be done to move away from purely instrumental and extrinsic reasons for partnering towards recognition of the integrative and intrinsic value that partnering can offer, both of which are likely to be derived from a deeper appreciation of the importance of inter-personal relationships. 


\section{Instrumental}

Partners work together in order to achieve SDG targets as part of their organizational and individual missions and work.

Extrinsic

Partners work together to meet organizational and individual mandates for achieving SDG targets in order to avoid sanctions and/or obtain clear rewards, e.g. improved reputation; organizational rankings or recognition for individual efforts.

\section{Integrative}

Partners work together in order to interact with a broader collaborative community through joinedup, holistic and traversal approaches to the SDGs with other organizations and individuals.

Intrinsic

Partners work together because of promising prospects for individual and organizational learning and growth linked to the SDGs.

Figure 3. Motivations for partnering for the Sustainable Development Goals (SDGs).

To explore this idea in more detail, Figure 4 sets out some of the assumptions that may be made in relation to the instrumental and extrinsic, and integrative and intrinsic character and values of a partnership. Within the instrumental category, these are likely to revolve around the importance of impact and how it will be achieved. This results-based focus suggests a pragmatic attitude towards other partners, with acknowledgement that each partner is able to contribute different resources and align around the achievement of desired goal(s). An integrative stance, meanwhile, will see value in the process of developing strong relationships and processes as well as achieving results. Attention will be paid to the need for joined-up approaches that involve all the partners working together closely while regularly reviewing their connections. In this way of working there will be acknowledgement that effective partnering processes will support the realization of results and attainment of goal(s).

\section{Instrumental}

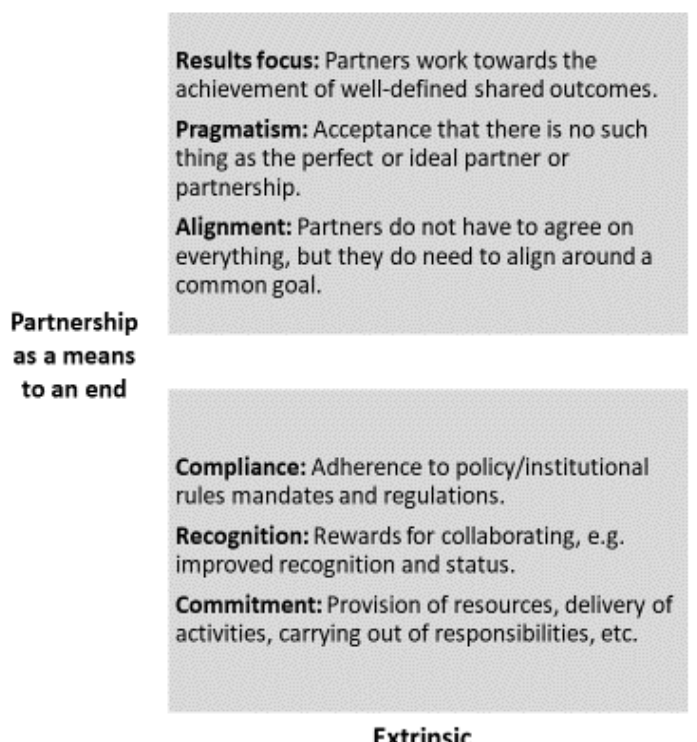

Integrative

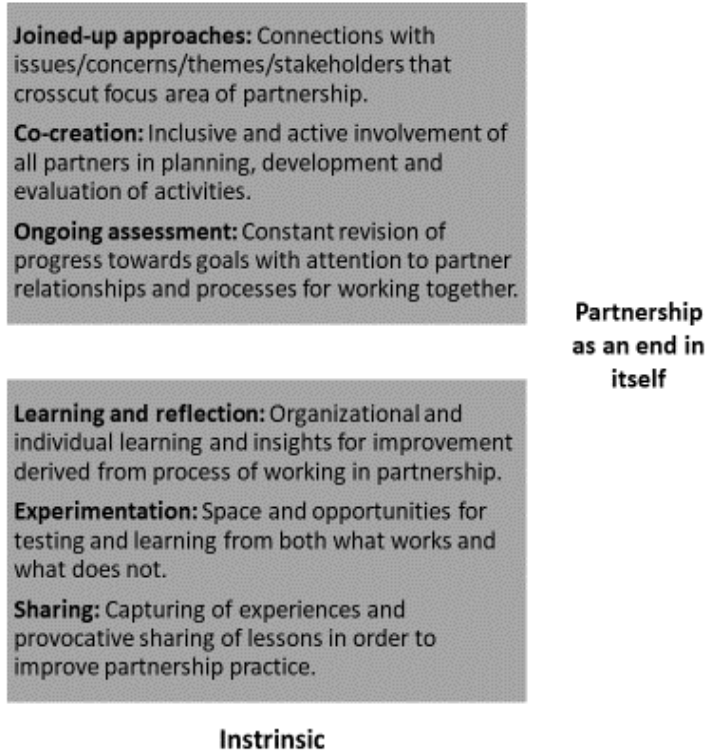

Figure 4. Relational values that motivate participation in partnerships. 
Considerations in the extrinsic classification are likely to center around the need for adherence to organizational mandates. Such mandates may promote partnering by offering positive incentives for engaging in collaborative initiatives and/or sanctions for not doing so. Emphasis will thus be placed on commitments to deliver, contribute and allocate resources as well as to carry out agreed tasks in order to achieve partnership goals. Intrinsic dimensions, meanwhile, will focus on the value of partnering in and of itself, with acknowledgement of the satisfaction that may be obtained by working in collaboration, particularly in relation to the learning gained from engaging in collaborative processes which can be tested and shared with others.

The elements outlined in Figure 4 are not exhaustive and are intended to offer an indication of some of the relational values that might be considered in each category. It is also true that partnering and other collaborative relationships must be viewed as dynamic, both relative to their specific and changing operational contexts and to the continual negotiation that takes place between partners at both individual and organizational levels regarding the terms and conditions of their evolving relationship [11,42]. We believe that appreciation of underlying emergent processes is central to an understanding of how relational values in partnerships may be deepened.

\section{Deepening Relational Values in Partnerships}

The challenging nature of building collaborative relationships across distinct geographical, cultural, sectoral and organizational cultures has been widely commented upon $[33,42,44,52,154,160]$. Some of the difficulties faced include: " ... environmental constraints; diversity in organizational aims; barriers in communication; and difficulties in developing joint modes of operating, managing perceived power imbalances, building trust, and managing the logistics of working with geographically dispersed partners" [161] (p. 117). It has also been observed that these challenges are more easily addressed as partner relationships become consolidated $[11,33,95,154,162]$. This suggests that the movement of a partnership away from stances that are instrumental and extrinsic towards those that are more integrative and intrinsic is likely to evolve over time. In this regard, the framework presented in Figure 4 may be of value as a practical discussion or review tool for partners as they work through different phases of relationship-building.

Relational difficulties during the initial stages of a partnership or other collaborative arrangements frequently relate to a lack of trust about different partner motivations or capacity for collaborating which is compounded by differences in partner approaches, cultures and behaviors [33,42,95,160]. Movement towards relationships that are centered around more intrinsic and integrative partnership factors may thus be more easily achieved if individual partner representatives know, or have familiarized themselves, with the mission, values and trajectories of their proposed partners. This is endorsed by Brinkerhoff [154], who notes that, "the more partners know and understand of each other's mission, track record, operations, and constraints in advance of the partnership, the less learning and trust building has to occur in the context of implementation" (p. 224).

Familiarization is likely to further assist relational connections during the initial stages of a partnership's formation when the specific motivations for different partners (both individual and organizational) to work together may be unclear or misunderstood [143,154,163]. By encouraging clarity around the fact that a common goal can be reached even though the aims and approaches of partners may differ, and encouraging partners to make their incentives for working together explicit, the quality of collaborative relationships may be enhanced [144,154,163]. Relationships can also be deepened by generating common understandings and agreement on joint goals, and ensuring acknowledgment of the different skills, competencies and resources that each partner brings to the partnership so that different contributions are valued equitably and their complementary nature reinforced [42].

As a partnership develops, challenges around accountability and the inclusion and engagement of partner organizations and their representatives may emerge [95,154,160,162]. These challenges are often linked to real or perceived power imbalances among partners and to their associated 
dynamics [154,160]. To foster the "mutuality" and "reciprocal accountability" required for successful partnership relationships [154], governance structures and procedures that encourage dialogue and communication, are responsive to the needs of partners and wider stakeholders, and promote experimentation, learning and reflection are critical [53,154,162,164].

An environment that is conducive to individual trust-building is central to the integrative and intrinsic factors outlined in Figure 4 and can assist the development of a unique partnership identity that consolidates relationships and binds partners together more firmly [154]. This 'we' rather than 'us' and 'them' mentality strengthens "partnership embeddedness" and the ability of partners to better address challenges [98] (p. 421). Such "embeddedness" also implies a progression away from the purely instrumental and extrinsic notions of partnership depicted in Figure 4 towards the institutionalization of more joined-up, reflective and co-created approaches [165]. Here, as noted by Seitanidi and Crane [98], personal connections play a crucial role: "when individuals develop a personal relationship of trust within the partnership then the level of embeddedness of the relationship becomes more evident" (p. 422).

In response to calls for improved monitoring of partner relationships [11,144,154,164], the framework in Figure 4 may also be used to assist assessments of partner relationships and process issues. This may be achieved by encouraging partners to reflect at regular intervals over the lifetime of a partnership on how they view their work together and in which quadrant(s) they believe their partnership currently 'sits'. If there is consensus that partners are primarily positioned in the instrumental and extrinsic quadrants, the question of how far partners aspire to make lasting and meaningful contributions to the SDGs may be studied by inquiring into the possibilities for embracing the integrative and intrinsic values that could enhance the prospects of achieving transformational change.

Finally, a better understanding of relational problems and possible solutions to address them are likely to be supported when there is a strong culture of learning from, and sharing among, individuals and organizations within and between partnerships and other collaborative arrangements. The need for imaginative and robust mutual learning exchange is highlighted in the intrinsic quadrant of Figure 4 and may be encouraged by active promotion of learning connections across diverse contexts and domains, and among relationships that are inter-personal, intra-organizational, inter organizational, cross-sectoral and multi-stakeholder (see Table 1). The creation of 'safe spaces' that allow for critical debate and reflection on both partnership successes and failures, and the nature of the relationships that inform them, may also facilitate the development of transformational partnerships for the SDGs $[38,166]$.

\section{Conclusions}

If, as the organizational consultant and psychotherapist Esther Perel asserts, "the quality of our relationships determines the quality of our lives" [167], then the quality of both our individual and organizational relationships will also determine the quality of the partnerships that are developed to achieve the SDGs. This paper suggests that if partnerships are to meet the United Nations transformational and inclusive agenda for the SDGs, then the role that interpersonal connections play within them, and how these link to organizational interactions in multi-stakeholder partnerships, must be given greater consideration. This will involve inquiry and dialogue around the links between these two domains, and how the values, motivations and dynamics they encompass influence the development, influence and impact of diverse collaborative arrangements.

Our conceptual article indicates that exploring partnerships for the SDGs would benefit from further consideration of academic fields such as OD and practitioner ideas like relational intelligence, as well as the application of established psychological and psychoanalytical approaches. In a related vein, it is also worth noting that recognition of the value of psychology in building and supporting sustainable development is receiving increased attention [168,169]. According to Di Fabio [169], the "psychology of sustainability and sustainable development" rests upon approaches and leadership 
that design and construct organizational development and well-being through "the promotion of relationships and positive narratives in organizational contexts in everyday life." It is our belief that acknowledgement of the importance of personal relationships and narratives in partnership and other collaborative arrangements has the potential to ensure meaningful and lasting contributions to the SDGs that might ultimately "transform our world" [20,21].

Author Contributions: Conceptualization, D.F.M. and L.S.; investigation, L.S. and D.F.M.; resources, D.F.M. and L.S.; writing - original draft preparation, L.S.; writing-review and editing, L.S. and D.F.M.; visualization, L.S. All authors have read and agreed to the published version of the manuscript.

Funding: This research received no external funding.

Acknowledgments: The authors would like to thank colleagues at the Innovation and Technology for Development Centre, Universidad Politécnica de Madrid and the Initiative for Leadership and Sustainability (IFLAS), University of Cumbria for encouraging their work.

Conflicts of Interest: The authors declare no conflict of interest.

\section{References}

1. The Tate is a family of four art galleries in: London, Liverpool and Cornwall known as Tate Modern, Tate Britain, Tate Liverpool and Tate St Ives, which awards the annual Tate Turner Prize. The Turner Prize is named after the English painter J. M. W. Turner and was first awarded in 1984. Each year the Turner Prize jury shortlist four artists for an outstanding exhibition or other presentation. Available online: https://www.tate.org.uk/art/turner-prize (accessed on 2 June 2020).

2. Dafoe, T. As a 'Statement of Solidarity,' the 2019 Turner Prize Is Awarded to All Four Nominees at Once. Artnet. 3 December 2019. Available online: https://news.artnet.com/art-world/2019-turner-prize-winner-1721373 (accessed on 2 June 2020).

3. Higgins, C. Interview: 'It's about Solidarity': The Artists Who Hijacked the Turner Prize Speak Out. The Guardian. 4 December 2019. Available online: https://www.theguardian.com/artanddesign/2019/dec/04/ its-about-solidarity-the-artists-who-hijacked-the-turner-prize-speak-out (accessed on 2 June 2020).

4. $\quad$ BBC Interview. Radio 4 Today. 4 December 2019. Available online: https://www.bbc.co.uk/programmes/ m000bxh8 (accessed on 2 June 2020).

5. Seitanidi, M.M.; Ryan, A. A critical review of forms of corporate community involvement: From philanthropy to partnerships. Int. J. Nonprofit Volunt. Sect. Mark. 2007, 12, 247-266. [CrossRef]

6. Merriam-Webster Online Dictionary. Available online: https:/www.merriam-webster.com/dictionary/ relationship (accessed on 2 June 2020).

7. Leadbeater, C. It's Co-Operation, Stupid: Why Richard Dawkins, Thomas Hobbes and Milton Friedman Got It Wrong; Institute for Public Policy Research: London, UK, 2012.

8. Sennett, R. Together: The Rituals and Pleasures of Cooperation; Penguin Books: London, UK, 2013.

9. Eisler, R. Human possibilities: The interaction of biology and culture. Interdiscip. J. Partnersh. Stud. 2015, 1, 1-39. [CrossRef]

10. Bregman, R. Humankind: A Hopeful History; Bloomsbury Publishing PLC: London, UK, 2020.

11. Battisti, M. Below the surface, The challenges of cross-sector partnerships. J. Corp. Citizsh. 2009, 35, 95-108. Available online: https://www.jstor.org/stable/jcorpciti.35.95 (accessed on 2 June 2020).

12. Pless, N.M.; Maak, T. Relational intelligence for leading responsibly in a connected world. Acad. Manag. Proc. 2005, 2005, I1-I6. [CrossRef]

13. Ellison, J. How Esther Perel Became the People's Therapist. FT Magazine. 18 May 2018. Available online: https://www.ft.com/content/3f8d5a7e-5895-11e8-b8b2-d6ceb45fa9d0 (accessed on 2 June 2020).

14. Burjek, A. Relational Intelligence Can Give Companies a Leg Up. Workforce. 6 June 2019. Available online: https://www.workforce.com/uk/news/relational-intelligence-can-give-companies-a-leg-up (accessed on 2 June 2020).

15. Five to Nine. On Building Relational Intelligence. Medium. 31 January 2020. Available online: https: //medium.com/@info_37650/on-building-relational-intelligence-28faf1dbaf01 (accessed on 4 July 2020). 
16. Perel, E. Business Relationships: What Couples Therapy Can Teach Us About Conflict in the Workplace. Esther Perel Blog. 2020. Available online: https:/estherperel.com/blog/conflict-in-the-workplace (accessed on 4 July 2020).

17. Murphy, H. Esther Perel's Radical Workplace Empathy. Rolling Stone. 19 March 2020. Available online: https:/www.rollingstone.com/culture/culture-features/esther-perel-therapist-podcasthows-work-interview-969632/ (accessed on 4 July 2020).

18. Van Tulder, R. Business and the Sustainable Development Goals: A Framework for Effective Corporate Involvement. Rotterdam School of Management, Erasmus University, 2018. Available online: https://www.rsm.nl/fileadmin/Images_NEW/Positive_Change/Business_and_Sustainable_ Development_Goals_-_Positive_Change_0_Rob_van_Tulder.pdf (accessed on 7 July 2020).

19. Moreno-Serna, J.; Sánchez-Chaparro, T.; Mazorra, J.; Arzamendi, A.; Stott, L.; Mataix, C. Transformational Collaboration for the SDGs: The Alianza Shire's Work to Provide Energy Access in Refugee Camps and Host Communities. Sustainability 2020, 12, 539. [CrossRef]

20. United Nations. Transforming Our World: The 2030 Agenda for Sustainable Development; Resolution 70/1 Adopted by the United Nations General Assembly on 25 September 2015; United Nations: New York, NY, USA, 2015. Available online: https://sustainabledevelopment.un.org/post2015/transformingourworld (accessed on 4 July 2020).

21. United Nations. The road to dignity by 2030: Ending poverty, transforming all lives and protecting the planet. In Synthesis Report of the Secretary-General on the Post-2015 Sustainable Development Agenda; United Nations: New York, NY, USA, 2014. Available online: https://www.un.org/disabilities/documents/ reports/SG_Synthesis_Report_Road_to_Dignity_by_2030.pdf (accessed on 4 July 2020).

22. Snyder, H. Literature review as a research methodology: An overview and guidelines. J. Bus. Res. 2019, 104, 333-339. [CrossRef]

23. Torraco, R.J. Writing Integrative Literature Reviews: Guidelines and Examples. Hum. Resour. Dev. Rev. 2005, 4, 356-367. [CrossRef]

24. Seale, C.; Gobo, G.; Gubrium, J.F.; Silverman, D. Qualitative Research Practice; Sage: London, UK, 2007.

25. Ritchie, J.; Lewis, J.C.; McNaughton Nicholls, C.; Ormston, R. Qualitative Research Practice; A Guide for Social Science Students and Researchers, Sage: London, UK, 2013.

26. Murphy, D.F.; Bendell, J. In the Company of Partners: Business, Environmental Groups and Sustainable Development Post-Rio; The Policy Press: Bristol, UK, 1997.

27. Murphy, D.F. The Partnership Paradox: Business-NGO Relations on Sustainable Development in the International Policy Arena. Ph.D. Thesis, School for Policy Studies, University of Bristol, Bristol, UK, 1998. Unpublished.

28. Murphy, D.F. The UN and Business: Global Partnership in Action. In Partnership Matters: Current Issues in Cross-Sector Collaboration, Special ed.; The Partnering Initiative: London, UK, 2006; Volume 4, pp. 19-23. Available online: https://hepartneringinitiative.org/wp-content/uploads/2014/08/PartnershipMatters4.pdf (accessed on 30 August 2020).

29. Bendell, J.; Murphy, D.F. The A-Z of Corporate Social Responsibility, 2nd ed.; Visser, W., Matten, D., Pohl, M., Tolhurst, T., Eds.; Wiley: Chichester, UK, 2010; pp. 307-309.

30. Stott, L. Conflicting Cultures: Lessons from a UN-Business Partnership. In Making a Difference, Exploring Issues in Partnering Practice Series; International Business Leaders Forum: London, UK, 2007.

31. Rein, M.; Stott, L. Working together: Critical perspectives on six cross-sector partnerships in Southern Africa. J. Bus. Ethics 2009, 90, 79-89. [CrossRef]

32. Stott, L. Partnerships for Innovation in Access to Basic Services; Multilateral Investment Fund/Inter-American Development Bank, Washington and itdUPM: Madrid, Spain, 2014; Available online: http://www.itd.upm.es/portfolio/alianzas-para-la-innovacion-en-el-acceso-serviciosbasicos-cinco-estudios-de-caso/?lang=en (accessed on 7 July 2020).

33. Stott, L. Partnership and Social Progress: Multi-Stakeholder Collaboration in Context. Ph.D. Thesis, University of Edinburgh, Edinburgh, UK, 2017.

34. Independent Group of Scientists appointed by the Secretary-General. Global Sustainable Development Report 2019: The Future is Now-Science for Achieving Sustainable Development; United Nations: New York, NY, USA, 2019. 
35. Gupta, J.; Vegelin, C. Sustainable development goals and inclusive development. Int. Environ. Agreem. 2016, 16, 433-448. [CrossRef]

36. Mahn, T.C. Accountability for Development Cooperation Under the 2030 Agenda; Discussion Paper, No. 10; Deutsches Institut für Entwicklungspolitik (DIE): Bonn, Germany, 2017.

37. Schleicher, J.; Schaafsma, M.; Vira, B. Will the Sustainable Development Goals address the links between poverty and the natural environment? Curr. Opin. Environ. Sustain. 2018, 34, 43-47. [CrossRef]

38. Stott, L.; Scoppetta, A. Partnerships for the Goals: Beyond SDG 17. Diecisiete 2020, 2, 29-38. [CrossRef]

39. Weber, H. Politics of 'Leaving No One Behind': Contesting the 2030 Sustainable Development Goals Agenda. Globalizations 2017, 14, 399-414. [CrossRef]

40. Horan, D.A. New Approach to Partnerships for SDG Transformations. Sustainability 2019, 11, 4947. [CrossRef]

41. Austin, J.E.; Seitanidi, M.M. Collaborative value creation: A review of partnering between nonprofits and businesses: Part I. Value creation spectrum and collaboration stages. Nonprofit Volunt. Sect. Q. 2012, 41, 726-758. [CrossRef]

42. Caplan, K.; Stott, L. Defining our terms and clarifying our language. In Partnership—As a Strategy for Social Innovation and Sustainable Change; Svensson, L., Nilsson, B., Eds.; Santérus Academic Press: Stockholm, Sweden, 2008; pp. 23-35.

43. Pearson, L. Partners in Development: Report of the Commission on International Development; Pall Mall Press: London, UK, 1969.

44. Pattberg, P.; Widerberg, O. Transnational multistakeholder partnerships for sustainable development: Conditions for success. Ambio 2016, 45, 42-51. [CrossRef] [PubMed]

45. Information Derived from Searches on the Terms 'Partner' and 'Partnership' in Online Etymology Dictionary. Available online: https://www.etymonline.com/ (accessed on 2 June 2020).

46. United Nations. Towards Global Partnerships; Resolution A/Res/55/215; adopted by the General Assembly on 21 December 2000; United Nations General Assembly: New York, NY, USA, 2001.

47. United Nations. Towards Global Partnerships: A Principle-Based Approach to Enhanced Cooperation between the United Nations and All Relevant Partners; Resolution A/Res/73/254; adopted by the General Assembly on 20 December 2018; United Nations General Assembly: New York, NY, USA, 2019.

48. United Nations. The Future We Want: Outcome Document of the United Nations Conference on Sustainable Development; United Nations: Rio de Janeiro, Brazil, 2012.

49. Creech, H.; Paas, L.; Oana, M. Report for the SEED Initiative Research Programme: Typologies for Partnerships for Sustainable Development and for Social and Environmental Enterprises: Exploring SEED winners through two lenses; SEED Initiative and the International Institute for Sustainable Development (IISD): Winnipeg, MB, Canada, 2008.

50. At the World Summit on Sustainable Development (WSSD) Type I partnership arrangements promoted by governments were distinguished from Type II partnerships or 'voluntary' coalitions among different actors. See Piest, U. In A Preliminary Analysis of the Inter-Linkages within WSSD "Type II" Partnerships; Work in Progress; Public Affairs Section, United Nations University: Tokyo, Japan, 2003; Volume 17, pp. $25-27$.

51. Googins, B.K.; Rochlin, S.A. Creating the partnership society: Understanding the rhetoric and reality of cross-sectoral partnerships. Bus. Soc. Rev. 2000, 105, 127-144. [CrossRef]

52. Tomlinson, F. Idealistic and pragmatic versions of the discourse of partnership. Organ. Stud. 2005, 26, 1169-1171. [CrossRef]

53. Selsky, J.W.; Parker, B. Cross-Sector Partnerships to Address Social Issues: Challenges to Theory and Practice. J. Manag. 2005, 31, 849-873. [CrossRef]

54. Murphy, D.F. In the Company of Partners-Businesses, NGOs and Sustainable Development: Towards a Global Perspective. In Environmentalist and Business Partnerships: A Sustainable Model? Aspinwall, R., Smith, J., Eds.; The White Horse Press: Cambridge, UK, 1996.

55. Mandell, M.; Steelman, T. Understanding what can be accomplished through interorganizational innovations. The importance of typologies, context and management strategies. Public Manag. Rev. 2003, 5, 197-224. [CrossRef]

56. Geddes, M.; Davies, J.; Fuller, C. Evaluating Local Strategic Partnerships: Theory and practice of change. Local Gov. Stud. 2007, 33, 97-116. [CrossRef] 
57. Bäckstrand, K.; Kylsäter, M. Old Wine in New Bottles? The Legitimation and Delegitimation of UN Public-Private Partnerships for Sustainable Development from the Johannesburg Summit to the Rio+20 Summit. Globalizations 2014, 11, 331-347. [CrossRef]

58. Austin, J.E. Strategic collaboration between nonprofits and businesses. Nonprofit Volunt. Sect. Q. 2000, 29, 69-97. [CrossRef]

59. Van den Brande, L. Multilevel Governance and Partnership. The Van den Brande Report, Prepared for Commissioner for Regional and Urban Policy Johannes Hahn, European Commission, Brussels. 2014. Available online: https:/capacitycooperation.danube-region.eu/wp-content/uploads/sites/3/2019/09/VanDen-Brande-Report_MLG-and-Participation.pdf (accessed on 6 July 2020).

60. Murphy, D.F.; Bendell, J. Partners in Time? Business, NGOs and Sustainable Development; UNRISD Discussion Paper 109; UN Research Institute for Social Development (UNRISD): Geneva, Switzerland, 1999.

61. Brinkerhoff, D.W.; Brinkerhoff, J.M. Partnerships between international donors and non-governmental development organizations: Opportunities and constraints. Int. Rev. Adm. Sci. 2004, 70, 253-270. [CrossRef]

62. Utting, P.; Zammit, A. United Nations-Business Partnerships: Good intentions and contradictory agendas. J. Bus. Ethics 2009, 90, 39-56. [CrossRef]

63. Ashman, D. Strengthening North-South partnerships for sustainable development. Nonprofit Volunt. Sect. Q. 2001, 30, 74-98. [CrossRef]

64. Kelly, L.; Roche, C. Partnerships for Effective Development; Australian Council for International Development (ACFID): Canberra, Australia, 2014.

65. Tennyson, R. Emerging models of development partnerships, what do partnership brokers need to know? In Thinking in Progress Paper; Partnership Brokers Association: London, UK, 2012.

66. Perel, E. Mating in Captivity: Sex, Lies and Domestic Bliss; Hodder: London, UK, 2007.

67. Perel, E. The State of Affairs: Rethinking Infidelity; HarperCollins: New York, NY, USA, 2017.

68. Chopra, V.; Arora, V.M.; Saint, S. Will You Be My Mentor? Four Archetypes to Help Mentees Succeed in Academic Medicine. JAMA Intern. Med. 2018, 178, 175-176. [CrossRef]

69. Detsky, A.S.; Baerlocher, M.O. Academic Mentoring-How to Give It and How to Get It. J. Am. Med Assoc. 2007, 297, 2134-2136. [CrossRef]

70. Greenfield, E.A.; Reyes, L. Continuity and Change in Relationships with Neighbors: Implications for Psychological Well-being in Middle and Later Life. J. Gerontol. Ser. B 2015, 70, 607-618. [CrossRef]

71. Wilson, A.E. Partnership and Private Corporations; Lasalle Extension University: Chicago, IL, USA, 1912.

72. Crosby, B.C.; Bryson, J.B. Integrative leadership and the creation and maintenance of cross-sector collaborations. Leadersh. Q. 2010, 21, 211-230. [CrossRef]

73. Cullen, K.; Willburn, P.; Chrobot-Mason, D.; Palus, C. Networks: How Collective Leadership Really Works; Center for Creative Leadership: Cincinnati, OH, USA, 2014.

74. Ibarra, H.; Hansen, M. Are You a Collaborative Leader? Harv. Bus. Rev. 2011, 89, 68-75. Available online: https://hbr.org/2011/07/are-you-a-collaborative-leader (accessed on 6 July 2020).

75. Johnstone, S.; Ackers, P.; Wilkinson, A. The British partnership phenomenon: A ten year review. Hum. Resour. Manag. J. 2009, 19, 260-279. [CrossRef]

76. Hamel, G.Y.; Doz, Y.; Prahalad, C.K. Collaborate with your competitors-And win. Harv. Bus. Rev. 1989, 67, 133-139.

77. Kanter, R.M. Collaborative Advantage: The Art of Alliances. Harv. Bus. Rev. 1994, 74, 96-108.

78. Swientozielskyi, S. Business Partnering. A Practical Handbook; Routledge: New York, NY, USA, 2016.

79. Todeva, E.; Knoke, D. Strategic Alliances and Models of Collaboration. Manag. Decis. 2005, 43, $123-148$. [CrossRef]

80. Lewis, M.K. The Trans-Pacific Partnership: New Paradigm of Wolf in Sheep's Clothing? Boston Coll. Int. Comp. Law Rev. 2011, 34, 27-52.

81. Abrahamsen, R. The power of partnerships in global governance. Third World Q. 2004, 25, $1453-1467$. [CrossRef]

82. Crawford, G. Partnership or power? Deconstructing the 'Partnership for Governance Reform' in Indonesia. Third World Q. 2003, 24, 139-159. [CrossRef]

83. Johnson, H.; Wilson, G. North-South/South-North partnerships: Closing the 'mutuality gap'. Public Adm. Dev. 2006, 26, 71-80. [CrossRef] 
84. Benneworth, P. (Ed.) University Engagement with Socially Excluded Communities; Springer: New York, NY, USA, 2013.

85. Taylor, J. Understanding international partnerships, a theoretical and practical approach. Perspect. Policy Pract. High. Educ. 2016, 20, 44-50. [CrossRef]

86. Reed, A.M.; Reed, D.R. Partnerships for Development: Four Models of Business Involvement. J. Bus. Ethics 2009, 90, 3-37. [CrossRef]

87. Global Compact LEAD Task Force. Catalyzing Transformational Partnerships Between the United Nations and Business; The Global Compact LEAD Task Force on UN-Business Partnerships: New York, NY, USA, 2011.

88. Nelson, J. Building Partnerships, Cooperation between the United Nations System and the Private Sector; United Nations Publications: New York, NY, USA, 2002.

89. Utting, P.; Zammit, A. Running in the Dark? The Rise of United Nations-Business Partnerships; Paper for UNRISD; UNRISD: Geneva, Switzerland, 2006.

90. Coombe, D. Corporate Citizenship: An expression of love. J. Corp. Citizsh. 2011, 42, 93-102.

91. Lee, L. Business-community partnerships: Understanding the nature of partnership. Corp. Gov. 2011, 11, 29-40. [CrossRef]

92. Loza, J. Business-community partnerships: The case for community organization capacity building. J. Bus. Ethics 2004, 53, 297-311. [CrossRef]

93. Brinkerhoff, D.W. Exploring state-civil society collaboration: Policy partnerships in developing countries. Nonprofit Volunt. Sect. Q. 1999, 28, 59-86. [CrossRef]

94. Brinkerhoff, J.M. Government-Nonprofit Partnership: A Defining Framework. Public Adm. Dev. 2002, 22, 19-30. [CrossRef]

95. Gazley, B. Linking collaborative capacity to performance measurement in government-nonprofit partnerships. Nonprofit Volunt. Sect. Q. 2010, 39, 653-673. [CrossRef]

96. Gazley, B.; Brudney, J.L. The purpose (and perils) of government-nonprofit partnership. Nonprofit Volunt. Sect. Q. 2007, 36, 389-415. [CrossRef]

97. Heap, S. NGO-Business partnerships, research-in-progress. Public Manag. 2000, 2, 555-563. [CrossRef]

98. Seitanidi, M.M.; Crane, A. Implementing CSR through partnerships: Understanding the selection, design and institutionalization of nonprofit-business partnerships. J. Bus. Ethics 2009, 85, 413-429. [CrossRef]

99. Baker, E.A.; Homan, S.; Schonhoff, R.; Kreuter, M. Principles of practice for academic/ practice/community research partnerships. Am. J. Prev. Med. 1999, 16, 86-93. [CrossRef]

100. Kolk, A.; Van Tulder, R.; Kostwinder, E. Business and partnerships for development. Eur. Manag. J. 2008, 26, 262-273. [CrossRef]

101. Nelson, J. Business as Partners in Development: Creating Wealth for Countries, Companies and Communities; Prince of Wales Business Leaders Forum: London, UK, 1996.

102. Stadtler, L. Scaling up tripartite social partnerships, insights from the becoming perspective on change. J. Corp. Citizsh. 2016, 63, 96-118. [CrossRef]

103. Waddell, S. Core competencies: A key force in business-government-civil society collaborations. J. Corporate Citizsh. 2002, 7, 43-56. [CrossRef]

104. Warner, M.; Sullivan, R. (Eds.) Putting Partnerships to Work: Strategic Alliances for Development between Government, the Private Sector and Civil Society; Greenleaf Publishing: London, UK, 2004.

105. Kapelus, P. Mining, Corporate Social Responsibility and the "Community": The Case of Rio Tinto, Richards Bay Minerals and the Mbonambi. J. Bus. Ethics 2002, 39, 275-296. [CrossRef]

106. Sullivan, R. Building Trust through Governance: Lessons from Tri-sector Partnerships in the Extractive Industries. J. Corp. Citizsh. 2007, 25, 55-76. Available online: www.jstor.org/stable/jcorpciti.25.55 (accessed on 23 July 2020).

107. Bäckstrand, K. Multi-stakeholder partnerships for sustainable development: Rethinking legitimacy, accountability and effectiveness. Eur. Environ. 2006, 16, 290-306. [CrossRef]

108. Beisheim, M. Partnerships for Sustainable Development: Why and How Rio +20 Must Improve the Framework for Multi-Stakeholder Partnerships; SWP Research Paper, Stiftung Wissenschaft und Politik; German Institute for International and Security Affairs: Berlin, Germany, 2012. Available online: https://www.swp-berlin.org/ fileadmin/contents/products/research_papers/2012_RP03_bsh.pdf (accessed on 6 July 2020).

109. Glasbergen, P. Understanding partnerships for sustainable development analytically: The ladder of partnership activity as a methodological tool. Environ. Policy Gov. 2001, 21, 1-13. [CrossRef] 
110. Stott, L. Co-Production: Enhancing the Role of Citizens in Governance and Service Delivery. Technical Dossier No.4, Brussels: DG Employment, Social Affairs and Inclusion, EU, May 2018. Available online: https://op.europa.eu/en/publication-detail/-/publication/fbac90e1-c6b9-11e8-942401aa75ed71a1/language-en (accessed on 30 July 2020).

111. Voorberg, W.H.; Bekkers, V.J.J.M.; Tummers, L.G. A systematic review of co-creation and co-production: Embarking on the social innovation journey. Public Manag. Rev. 2014, 17, 1333-1357. [CrossRef]

112. Hanleybrown, F.; Kania, J.; Kramer, M. Channeling change: Making collective impact work. In Stanford Social Innovation Review; Stanford Center on Philanthropy and Civil Society, Stanford University: Palo Alto, CA, USA, 2012; pp. 1-8. Available online: https://ssir.org/articles/entry/channeling_change_making_collective_ impact_work (accessed on 6 July 2020).

113. Harwood, R. Putting Community in Collective Impact. In Stanford Social Innovation Review; Stanford Center on Philanthropy and Civil Society, Stanford University: Palo Alto, CA, USA, 7 April 2014; p. 5. Available online: https://ssir.org/articles/entry/putting_community_in_collective_impact (accessed on 6 July 2020).

114. Kania, J.; Kramer, M. Collective impact. In Stanford Social Innovation Review; Stanford Center on Philanthropy and Civil Society, Stanford University: Palo Alto, CA, USA, 2011; pp. 36-41. Available online: https: //ssir.org/articles/entry/collective_impact (accessed on 6 July 2020).

115. Granstrand, O.; Holgersson, M. Innovation ecosystems: A conceptual review and a new definition. Technovation 2020, 90-91, 102098. [CrossRef]

116. Mattila, P.; Eisenbart, B.; Kocsis, A.; Ranscombe, C.; Tuulos, T. Transformation Is a Game We Can't Play Alone: Diversity and Co-creation as Key to Thriving Innovation Ecosystems. In Research into Design for a Connected World. Smart Innovation, Systems and Technologies; Chakrabarti, A., Ed.; Springer: New York, NY, USA, 2019; pp. 151-162.

117. Andersen, S.K.; Mailand, M. The Role of Employers and Trade Unions in Multipartite Social Partnerships; The Copenhagen Centre: Copenhagen, Denmark, 2002.

118. itdUPM. Multiactor Partnerships for Innovation: From Public Private Partnerships to Public Private People Partnerships; Position Paper; Innovation and Technology for Development Centre, Technical University of Madid: Madrid, Spain, 2015. Available online: http://www.itd.upm.es/2015/05/27/multi-actor-partnershipsinnovation/?lang=en (accessed on 30 July 2020).

119. Ng, S.T.; Wong, J.M.W.; Wong, K.K.W. A public private people partnerships (P4) process framework for infrastructure development in Hong Kong. Cities 2013, 31, 370-381. [CrossRef]

120. Börzel, T.A.; Risse, T. Public-Private Partnerships: Effective and Legitimate Tools of International Governance? In Complex Sovereignty: On the Reconstitution of Political Authority in the 21st Century; Grande, E., Pauly, L.W., Eds.; University of Toronto Press: Toronto, ON, Canada, 2007.

121. Schäferhoff, M.; Campe, S.; Kaan, C. Transnational Public-Private Partnerships in International Relations: Making Sense of Concepts, Research Frameworks, and Results. Int. Stud. Rev. 2009, 11, 451-474. [CrossRef]

122. Gatignon, A.; Van Wassenhove, L.N. North Star Foundation: Paving the Road to Healthy Highways-A Partnership to Scale up HIV/AIDS Clinics in Africa; INSEAD Case 10/2008-5523; INSEAD Publishing: Fontainebleau, France, 2008.

123. Tomasini, R.; Van Wassenhove, L.N. From preparedness to partnerships: Case study research on humanitarian logistics. Int. Trans. Oper. Res. 2009, 16, 549-559. [CrossRef]

124. Moga, J. Disaster Mitigation Planning: The Growth of Local Partnerships for Disaster Reduction; Paper Presented at Regional Workshop on Best Practices in Disaster Mitigation; ADPC: Bangkok, Thailand, 2002. Available online: http://www.adpc.net/V2007/IKM/ONLINE\%20DOCUMENTS/downloads/ADUMP/MPI.pdf (accessed on 6 July 2020).

125. Sassa, K. ISDR-ICL Sendai Partnerships 2015-2025 for global promotion of understanding and reducing landslide disaster risk. Landslides 2015, 12, 631-640. [CrossRef]

126. Andonova, L.B.; Betsill, M.M.; Bulkeley, H. Transnational Climate Governance. Glob. Environ. Politics 2009, 9, 52-73. [CrossRef]

127. Bulkeley, H.; Castan Broto, V. Government by experiment? Global cities and the governing of climate change. Trans. Inst. Br. Geogr. 2013, 38, 361-375. [CrossRef]

128. Pinkse, J.; Kolk, A. Addressing the climate change-sustainable development nexus: The role of multi-stakeholder partnerships. Bus. Soc. 2012, 51, 176-210. [CrossRef] 
129. Van Huijstee, M.M.; Francken, M.; Leroy, P. Partnerships for sustainable development: A review of current literature. Environ. Sci. 2007, 4, 75-89. [CrossRef]

130. Carnwell, R.; Buchanan, J. Effective Practice in Health, Social Care and Criminal Justice: A Partnership Approach; Open University Press: Maidenhead, UK, 2008.

131. Magee, M. Qualities of enduring cross-sector partnerships in public health. Am. J. Surg. 2003, 185, $26-29$. [CrossRef]

132. Reich, M.R. (Ed.) Partnerships for Public Health; Harvard Series on Population and International Health; Harvard Center for Population and Development Studies: Cambridge, MA, USA, 2002.

133. Scoppetta, A. Successful Partnerships in Delivering Public Employment Services; Analytical Paper; European Commission: Brussels, Belgium, 2013.

134. Stott, L.; Scoppetta, A. Promoting Local Economic Development through partnerships in Europe. Ski. Work Theory Pract. J. 2013, 6, 2-12.

135. Makin, D.A.; Marenin, O. Let's Dance: Variations of Partnerships in Community Policing. Polic. A J. Policy Pract. 2017, 11, 421-436. [CrossRef]

136. Beeson, T.; McAllister, B.D.; Regenstein, M. Making the Case for Medical-Legal Partnerships: A Review of the Evidence; National Center for Medical-Legal Partnership, The George Washington University School of Public Health and Health Services: Washington, DC, USA, 2013. Available online: https:/www.medical-legalpartnership.org/wp-content/uploads/2014/03/Medical-LegalPartnership-Literature-Review-February-2013.pdf (accessed on 6 July 2020).

137. OECD. Together for Better Public Services: Partnering with Citizens and Civil Society; OECD Public Governance Reviews; OECD Publishing: Paris, France, 2011. [CrossRef]

138. Otiso, K.M. State, voluntary and private sector partnerships for slum upgrading and basic service delivery in Nairobi City, Kenya. Cities 2003, 20, 221-229. [CrossRef]

139. Kolk, A. Partnerships as a Panacea for Addressing Global Problems? On Rationale, Context, Actors, Impact and Limitations. In Social Partnerships and Responsible Business: A Research Handbook; Seitanidi, M., Crane, A., Eds.; Routledge: London, UK, 2013; pp. 15-41.

140. Austin, J.R.; Bartunek, J.M. Theories and Practices of Organizational Development. In Handbook of Psychology, Industrial and Organizational Psychology; John Wiley and Sons: Hoboken, NJ, USA, 2003; Volume 12, pp. 309-332.

141. Rothwell, W.J.; Stavros, J.M.; Sullivan, R.L. Organization Development, Transformation, and Change. In Practicing Organization Development: Transformation and Change, 4th ed.; Rothwell, W.J., Stavros, J.M., Sullivan, R.L., Eds.; Wiley: Hoboken, NJ, USA, 2015; pp. 11-25.

142. Creasey, T.; Jamieson, D.W.; Rothwell, W.J.; Severini, G. Exploring the Relationship between Organization Development and Change Management. In Practicing Organization Development: Transformation and Change, 4th ed.; Rothwell, W.J., Stavros, J.M., Sullivan, R.L., Eds.; Wiley: Hoboken, NJ, USA, 2015; pp. 330-337.

143. Sloan, P.; Oliver, D. Building trust in multi-stakeholder partnerships: Critical emotional incidents and practices of engagement. Organ. Stud. 2013, 34, 1835-1868. [CrossRef]

144. Caplan, K.; Gomme, J.; Mugabi, J.; Stott, L. Assessing Partnership Performance: Understanding the Drivers for Success; Building Partnerships for Development: London, UK, 2007.

145. Stott, L. (Ed.) Shaping Sustainable Change: The Role of Partnership Brokering in Optimising Collaborative Action; Greenleaf Publishing, Routledge: London, UK, 2018.

146. Tennyson, R. The Brokering Guidebook; The Partnering Initiative and International Business Leaders Forum: London, UK, 2005.

147. Scharmer, O.; Kaufer, K. Leading from the Emerging Future: From Ego-System to Eco-System Economics; Berret Koehler Publisher: San Francisco, CA, USA, 2013.

148. Senge, P.; Hamilton, H.; Kania, J. The dawn of system leadership. In Stanford Social Innovation Review; Stanford Center on Philanthropy and Civil Society, Stanford University: Palo Alto, CA, USA, 2015; pp. 27-33. Available online: https://ssir.org/articles/entry/the_dawn_of_system_leadership (accessed on 6 July 2020).

149. Waddock, S. From individual to institution: On making the world different. J. Bus. Ethics 2010, 94, 9-12. [CrossRef] 
150. Gino, F. Cracking the Code of Sustained Collaboration. In Harvard Business Review; Harvard Business Publishing: Brighton, Boston, November-December 2019. Available online: https://hbr.org/2019/11/crackingthe-code-of-sustained-collaboration (accessed on 2 June 2020).

151. Leary, M.R.; Acosta, J. Acceptance, Rejection and the Quest for Relational Value. In The Cambridge Handbook of Personal Relationships; Vangelisti, A.M., Perlman, D., Eds.; Cambridge University Press: Cambridge, UK, 2012.

152. Tennyson, R. The Partnering Toolbook; International Business Leaders Forum, London and Global Alliance for Improved Nutrition: Geneva, Switzerland, 2004.

153. Luke, M.A.; Sedikides, C.; Carnelley, K.B. Your Love Lifts Me Higher! The Energizing Quality of Secure Relationships. Personal. Soc. Psychol. Bull. 2012, 38, 721-733. [CrossRef]

154. Brinkerhoff, J.M. Assessing and improving partnership relationships and outcomes: A proposed framework. Eval. Program Plan. 2002, 25, 215-231. [CrossRef]

155. Dörnyei, Z. Motivation and motivating in the foreign language classroom. Mod. Lang. J. 1994, 78, $273-284$. [CrossRef]

156. Gardner, R.C. Integrative motivation and second language acquisition. In Motivation and Second Language Acquisition; Dörnyei, Z., Schmidt, R., Eds.; University of Hawaii Press: Honolulu, HI, USA, 2001.

157. Legault, L. Intrinsic and Extrinsic Motivation. In Encyclopaedia of Personality and Individual Differences; Zeigler-Hill, V., Shackelford, T.K., Eds.; Springer International Publishing: Cham, Switzerland, 2016.

158. Matsuzaki Carreira, J. New Framework of Intrinsic/Extrinsic and Integrative/Instrumental Motivation in Second Language Acquisition. Keiai J. Int. Stud. 2005, 16, 39-64.

159. Kimberly, N.A.; Clément, R.; Pelletier, L.G. Perceptions of Teachers' Communicative Style and Students' Intrinsic and Extrinsic Motivation. Mod. Lang. J. 1999, 83, 23-34. [CrossRef]

160. Huxham, C.; Vangen, S. Doing Things Collaboratively: Realizing the Advantage or Succumbing to Inertia? Organ. Dyn. 2004, 33, 190-201. [CrossRef]

161. Babiak, K.; Thibault, L. Challenges in multiple cross-sector partnerships. Nonprofit Volunt. Sect. Q. 2009, 38, 117-143. [CrossRef]

162. Caplan, K. Partnership Accountability: Unpacking the Concept; Practitioner Note Series; Building Partnerships for Development in Water and Sanitation: London, UK, 2005; Available online: http://www.bpdws.org/web/ d/doc_4.pdf?statsHandlerDone=1 (accessed on 30 August 2020).

163. Stott, L. Partnership fundamentals: Understanding organisational incentives. Rev. Esp. Desarro. Y Coop. 2017, 40, 27-37.

164. Stott, L. Partnerships for Sustainable Development, The Monitoring and Evaluation Challenge; Great Insights; European Centre for Development Policy Management (ECDPM): Maastricht, The Netherlands, 2018; pp. 28-30. Available online: https://ecdpm.org/great-insights/civil-society-business-same-direction/ partnerships-sustainable-development-monitoring-evaluation-challenge/ (accessed on 30 August 2020).

165. This resonates with the recent work of Jon Alexander. 2020. 'It doesn't have to be like this' where he advocates a shift in the relationship between Government and Citizen from the idea of 'us and them' to the notion of 'a larger us': "We need to build ... the Citizen story, where the role of government is neither all nor nothing, but in between: To equip and enable us, and to partner with us; to share as much information and power as possible, so that we can work together with government and with one another to create a new normal." See, Alexander, J. It doesn't have to be like this. Medium. 13 May 2020. Available online: https://medium.com/@jonjalex/it-doesnt-have-to-be-like-this-22f0884fbaf (accessed on 3 July 2020).

166. Beisheim, M.; Simon, N. Multi-Stakeholder Partnerships for Implementing the 2030 Agenda: Improving Accountability and Transparency. Analytical Paper for the 2016 ECOSOC Partnership Forum. 18 March 2016. Available online: https://www.un.org/ecosoc/sites/www.un.org.ecosoc/files/files/en/2016doc/partnershipforum-beisheim-simon.pdf (accessed on 20 August 2020).

167. Perel, E. Cited in Chattopadhyay, P. 'They have become the New Religion': Esther Perel Says we expect too much from Relationships. Out in the Open, CBC Radio. 15 February 2019. Available online: https://www.cbc.ca/radio/outintheopen/they-have-become-the-new-religion-esther-perelsays-we-expect-too-much-from-relationships-1.5000270 (accessed on 6 July 2020). 
168. Antonucci, T.C.; Bial, M.; Cox, C.; Finkelstein, R.; Marchado, L. The role of psychology in addressing worldwide challenges of poverty and gender inequality. Z. Psychol. 2019, 227, 95-104. [CrossRef]

169. Di Fabio, A. The Psychology of Sustainability and Sustainable Development for Well-Being in Organizations. Front. Psychol. 2017, 8, 1534. [CrossRef] [PubMed]

(C) 2020 by the authors. Licensee MDPI, Basel, Switzerland. This article is an open access article distributed under the terms and conditions of the Creative Commons Attribution (CC BY) license (http://creativecommons.org/licenses/by/4.0/). 